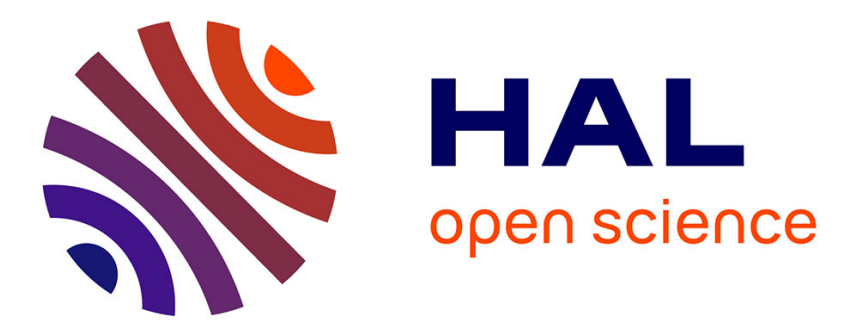

\title{
High-Order Sliding Mode Control of DFIG-Based Marine Current Turbine
}

Seifeddine Benelghali, Mohamed Benbouzid, Tarek Ahmed-Ali, Jean Frédéric

Charpentier, Fatiha Mekri

\section{- To cite this version:}

Seifeddine Benelghali, Mohamed Benbouzid, Tarek Ahmed-Ali, Jean Frédéric Charpentier, Fatiha Mekri. High-Order Sliding Mode Control of DFIG-Based Marine Current Turbine. IEEE IECON'08, Nov 2008, Orlando, United States. pp.1228-1233. hal-00531281

\section{HAL Id: hal-00531281 \\ https://hal.science/hal-00531281}

Submitted on 2 Nov 2010

HAL is a multi-disciplinary open access archive for the deposit and dissemination of scientific research documents, whether they are published or not. The documents may come from teaching and research institutions in France or abroad, or from public or private research centers.
L'archive ouverte pluridisciplinaire HAL, est destinée au dépôt et à la diffusion de documents scientifiques de niveau recherche, publiés ou non, émanant des établissements d'enseignement et de recherche français ou étrangers, des laboratoires publics ou privés. 


\title{
High-Order Sliding Mode Control of DFIG-Based Marine Current Turbine
}

\author{
S.E. Ben Elghali ${ }^{1}$, M.E.H. Benbouzid ${ }^{1}$, T. Ahmed-Ali ${ }^{1}$, J.F. Charpentier ${ }^{2}$ and F. Mekri ${ }^{2}$ \\ ${ }^{1}$ Laboratoire Brestois de Mécanique et des Systèmes (LBMS - EA 4325), University of Brest \\ IUT of Brest - Rue de Kergoat - CS 93837, 29238 Brest Cedex 03, France \\ Phone: +33 2980180 07; Fax: +33 2980166 43; E-mail: m.benbouzid@ieee.org \\ ${ }^{2}$ French Naval Academy Research Institute (IRENav - EA 3634), French Naval Academy - Lanveoc-Poulmic, BP 600, 29240 Brest Armées, France
}

\begin{abstract}
This paper deals with the speed control of a variable speed DFIG-based marine current turbine. Indeed, to increase the generated power and therefore the efficiency of a marine current turbine, a nonlinear controller has been proposed. DFIG has been already considered for similar applications particularly wind turbine systems using mainly PI controllers. However, such kinds of controllers do not adequately handle some of tidal resource characteristics such as turbulence and swell effects. Indeed, these may decrease marine current turbine performances. Moreover, DFIG parameter variations should be accounted for. Therefore, a robust nonlinear control strategy, namely high-order sliding mode control, is proposed. This control strategy relies on the resource and the marine turbine models that were validated by experimental data. The sensitivity of the proposed control strategy is analyzed regarding the swell effect as it is considered as the most disturbing one for the resource model. Tidal current data from the Raz de Sein (Brittany, France) are used to run simulations of a $7.5-\mathrm{kW}$ prototype over various flow regimes. Simulation results are presented and fully analyzed.
\end{abstract}

Index Terms-Marine current turbine (MCT), doubly-fed induction generator (DFIG), modeling, nonlinear control, highorder sliding mode.

\section{NOMENCLATURE}

$\begin{array}{ll}\text { DFIG } & =\text { Doubly-Fed Induction Generator; } \\ \text { MCT } & =\text { Marine Current Turbine; } \\ \rho & =\text { Fluid density; } \\ A & =\text { Cross-sectional area of the marine turbine; } \\ V_{t i d e} & =\text { Fluid speed; } \\ C_{p} & =\text { Power coefficient; } \\ C & =\text { Tide coefficient; } \\ V_{s t}\left(V_{n t}\right) & =\text { Spring (neap) tide current speed; } \\ s,(r) & =\text { Stator (rotor) index; } \\ d, q & =\text { Synchronous reference frame index; } \\ V(I) & =\text { Voltage (Current); } \\ P(Q) & =\text { Active (Reactive) power; } \\ \phi & =\text { Flux; } \\ T_{e m}\left(T_{m}\right) & =\text { Electromagnetic torque (Mechanical torque); } \\ R & =\text { Resistance } \\ L(M) & =\text { Inductance (Mutual inductance); } \\ \theta_{r} & =\text { Rotor position; }\end{array}$

This work is supported by Brest Métropole Océane (BMO) and the European Social Fund (ESF). It is also supported by the GDR SEEDS CNRS No2994 under the Internal Project HYDROLE. It is done within the framework of the Marine Renewable Energy Commission of the Brittany Maritime Cluster (Pôle Mer Bretagne).

$$
\begin{array}{ll}
\omega_{r}\left(\omega_{s}\right) & =\text { Angular speed (Synchronous speed) } \\
f & =\text { Viscosity coefficient; } \\
J & =\text { Rotor Inertia; } \\
p & =\text { Pole pair number. }
\end{array}
$$

\section{INTRODUCTION}

Only a fraction of the global ocean energy resource is to be found in sites which are economically feasible to explore with available technology. However, this fraction could still make a considerable contribution to electricity supply. This is the reason why the marine renewable sector is currently the focus of much industrial and academic research around the world [1]. Sites with attractive wave climate and intense tidal currents are abundant in the vicinity of the European coastline. It has been shown that $48 \%$ of the European tidal resource is in the UK, $42 \%$ in France, and $8 \%$ in Ireland. Three examples in France are shown in Fig. 1. The Raz Blanchard situated in Cap de la Hague experiences extreme tidal currents exceeding 8 knots and leading to a large amount of kinetic energy flux.

There are basically two ways of generating electricity from marine and tidal currents: by building a tidal barrage across an estuary or a bay in high tide areas, or by extracting energy from free flowing water (tidal kinetic energy). Within the last few decades, developers have shifted towards technologies that capture tidally-driven coastal currents or tidal stream [2]. The astronomic nature of this resource makes it predictable, to within $98 \%$ accuracy for decades, and independent of prevailing weather conditions. This predictability is critical to a successful integration of renewable energy in the electrical grid [3]. It is therefore obvious that there is a need to quantify the potential to generating electricity from these various sites [4].

In this context, this paper is dealing with the control of a DFIG-based marine current turbine.

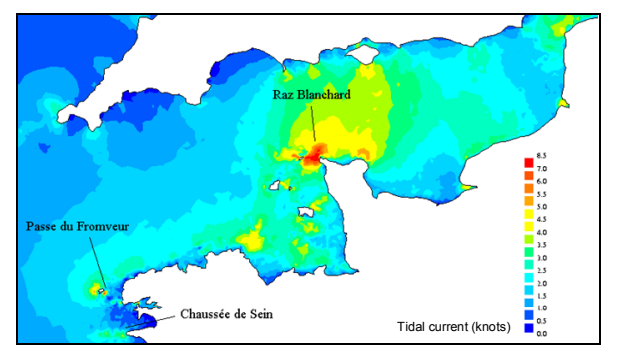

Fig. 1. Raz Blanchard, Fromveur, and Raz de Sein sites in the French western coast. 
It should be noted that when scanning the literature, one will find very few papers in this topic [5]. Therefore, to account for some of tidal resource characteristics such as turbulence and swell effects, and the DFIG parameter variation, a robust nonlinear control strategy, namely HOSM control, is proposed. This control strategy relies on the resource and the marine turbine models that were validated by experimental data. Tidal current data from the Raz de Sein (Brittany, France) are used to run simulations of a $7.5-\mathrm{kW}$ prototype over various flow regimes.

\section{MARINE CURRENT TURBINE MODELING}

The global scheme for a grid-connected marine current turbine is given by Fig. 2 .

\section{A. The Resource Model}

1) Resource Potential. The total kinetic power in a marine current turbine has a similar dependence to that of a wind turbine and is governed by the following equation [6-7].

$$
P=\frac{1}{2} \rho A V_{\text {tide }}^{3}
$$

However, a marine energy turbine can only harness a fraction of this power due to losses and (1) is modified as follows.

$P=\frac{1}{2} \rho C_{p} A V_{\text {tide }}^{3}$

For marine turbines, $C_{p}$ is estimated to be in the range $0.35-0.5$ [8].

2) Resource Model. Tidal current data are given by the SHOM (French Navy Hydrographic and Oceanographic Service) and is available for various locations in chart form. The SHOM available charts give, for a specific site, the current velocities for spring and neap tides. These values are given at hourly intervals starting at 6 hours before high waters and ending 6 hours after. Therefore, knowing tides coefficient, it is easy to derive a simple and practical model for tidal current speeds $V_{\text {tide }}$.

$$
V_{\text {tide }}=V_{n t}+\frac{(C-45)\left(V_{s t}-V_{n t}\right)}{95-45}
$$

Where 95 and 45 are respectively the spring and neap tide medium coefficient.

This first-order model is then used to calculate the tidal velocity each hour. The implemented model will allow the user to compute tidal velocities in a predefined time range. Figure 3 shows the model output for a month (March 2007) and for a year (2007).

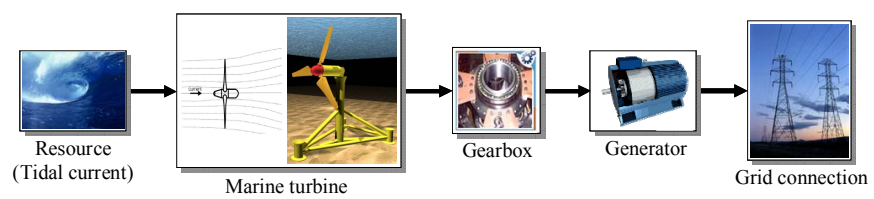

Fig. 2. Marine current turbine global scheme.
This adopted resource model has several advantages including its modularity not to mention its simplicity. Indeed, the marine turbine site can be changed, the useful current velocity can be adapted, and the time range taken into account can also be adapted from one month to one year.

\section{B. The Turbine Rotor Model}

The harnessing of the energy in a tidal flow requires the conversion of kinetic energy in a moving fluid, in this case water, into the motion of a mechanical system, which can then drive a generator. It is not too surprising, therefore, that many developers suggest using technology that mirrors that which has been successfully utilized to harness the wind, which is also a moving fluid [2]. Moreover, much of the technology is based upon the use of horizontal axis turbines, such as that shown in Fig. 4. Therefore, much can be transferred from the modeling and operation of wind turbines [9]. There are, however, a number of fundamental differences in the design and operation of marine turbines. Particular differences entail changes in force loadings, immersion depth, different stall characteristics, and the possible occurrence of cavitation [10-11].

Turbine rotor aerodynamics refers to the interaction of the wind turbine rotor with the incoming wind. The treatment of rotor aerodynamics in all current design codes is based on Glauert well-known, and well established Blade Element Momentum (BEM) theory [12]. The BEM method has therefore been used for the marine turbine rotor modeling. Indeed, it is widely used in the industry as a computational tool to predict aerodynamic loads and power of turbine rotors. It is relatively simple and computationally fast meeting the requirements of accuracy and control loop computational speed.

\section{The Generator Model}

The generator chosen for the marine current system was the DFIG [13].
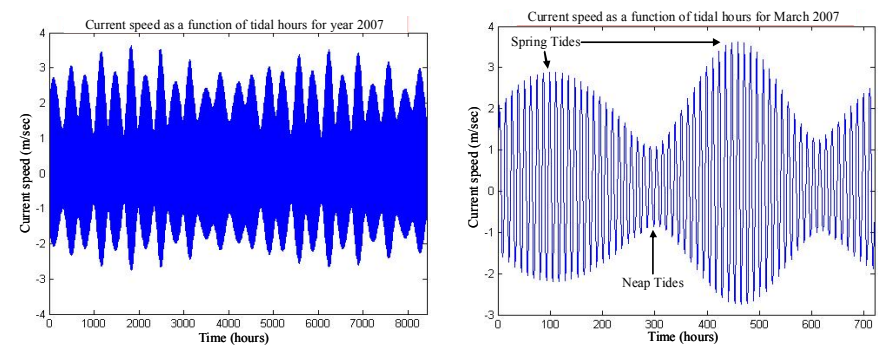

Fig. 3. Tidal velocity in the Raz de Sein for the year 2007 and March 2007.

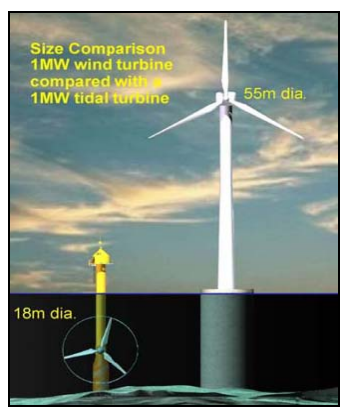

Fig. 4. Tidal turbine against an offshore wind turbine [C MCT]. 
DFIG-based marine turbines, as for wind turbines, will offer several advantages including variable speed operation, and four-quadrant active and reactive power capabilities. Such system also results in lower converter costs and lower power losses compared to a system based on a fully fed synchronous generator with full-rated converter. Moreover, the generator is robust and requires little maintenance [5], [14]. A schematic diagram of a DFIG-based generation system is shown in Fig. 5.

The control system is usually defined in the synchronous $d-q$ frame fixed to either the stator voltage or the stator flux [13]. For the proposed control strategy, the generator dynamic model written in a synchronously rotating frame $d-q$ is given by the following equation.

$$
\left\{\begin{array}{l}
\frac{d \phi_{d s}}{d t}=V_{d s}+R_{s} I_{d s}+\omega_{s} \phi_{q s} \\
\frac{d \phi_{q s}}{d t}=V_{q s}+R_{s} I_{q s}-\omega_{s} \phi_{d s} \\
\frac{d \phi_{d r}}{d t}=V_{d r}+R_{r} I_{d r}+\omega_{r} \phi_{q r} \\
\frac{d \phi_{q r}}{d t}=V_{q r}+R_{r} I_{q r}-\omega_{r} \phi_{d r} \\
\phi_{d s}=-L_{s} I_{d s}-M I_{d r} \\
\phi_{q s}=-L_{s} I_{q s}-M I_{q r} \\
\phi_{d r}=-L_{r} I_{d r}-M I_{d s} \\
\phi_{q r}=-L_{r} I_{q r}-M I_{q s} \\
T_{e m}=p M\left(I_{q s} I_{d r}-I_{d s} I_{q r}\right) \\
J \frac{d \omega}{d t}=T_{e m}-T_{m}-f \omega
\end{array}\right.
$$

\section{The VAriable Speed Control Strategy}

\section{A. Problem Formulation}

A common practice in addressing DFIG control problem is to use a linearization approach [15-20]. However, due to the tidal resource characteristics such as turbulence and swell effects and the inevitable uncertainties inherent in DFIGbased marine current turbines, such control methods come at the price of poor system performance and low reliability [21]. Hence the need for nonlinear and robust control to take into account these control problems [22-23].

In this context, sliding mode control seems to be an interesting approach.

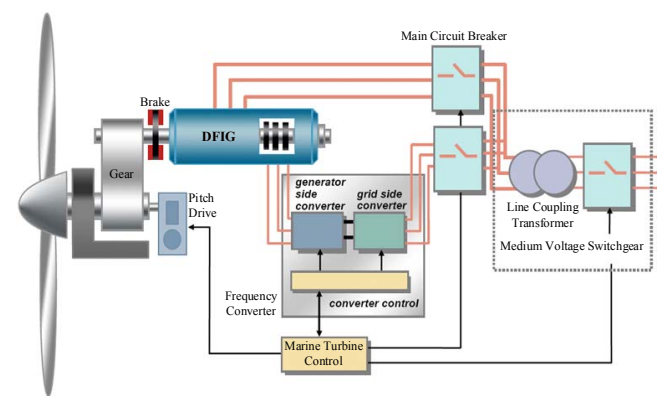

Fig. 5. Schematic diagram of a DFIG-based generation system.
Indeed, it is one of the effective nonlinear robust control approaches since it provides system dynamics with an invariant property to uncertainties once the system dynamics are controlled in the sliding mode [24]. Moreover, it is easy to implement.

For DFIG-based marine current turbines, sliding mode should provide a suitable control tool for conversion efficiency, torque oscillation smoothing [25] and robustness against electric grid disturbances [26]. Indeed, in an initial study, PI control has been adopted for speed tracking of DFIG-based marine current turbine [27]. This kind of controller is wellknown for its robustness and its simplicity for constant references. Its gains are computed by compensating the larger system time -constant and by guaranteeing a constant tracking error when the reference is a ramp. However, in case of marine current turbine, the generated reference signals are timevarying and the current sources may be turbulent, which makes the PI feedback not efficient.

\section{B. The Proposed Control Strategy}

The proposed control strategy is based on a step-by-step procedure: First, the speed reference $\omega_{\text {ref }}$ is generated by a Maximum Power Point Tracking (MPPT) strategy [28]. Then, an optimal electromagnetic torque, which ensures the rotor speed convergence to $\omega_{\text {ref }}$ is computed using the following mechanical equation.

$$
T_{\text {em_ref }}=T_{m}+f \omega-\alpha\left(\omega-\omega_{r e f}\right)+J \dot{\omega}_{r e f}
$$

where $\alpha$ is a positive constant. Afterwards, rotor current references are derived to ensure the DFIG torque and reactive power convergence the optimal torque and zero, respectively.

$$
\left\{\begin{array}{l}
I_{q r_{-} r e f}=-\frac{L_{s}}{p M} \frac{T_{e m_{-} r e f}}{\phi_{s d}} \\
I_{d r_{-} \text {ref }}=\frac{1}{M} \phi_{s d}
\end{array}\right.
$$

In order to ensure the rotor currents convergence to their references, a robust high-order sliding mode strategy is used [29]. Let us define the following surfaces.

$$
\left\{\begin{array}{l}
S_{1}=I_{d r}-I_{d r_{-} r e f} \\
S_{2}=I_{q r}-I_{q r_{-} r e f}
\end{array}\right.
$$

It follows that

$$
\left\{\begin{aligned}
\dot{S}_{1}= & \frac{L_{s}}{M^{2}-L_{r} L_{s}}\left(V_{d r}+R_{r} I_{d r}-\omega_{r}\left(L_{r} I_{q r}+M I_{q s}\right)-\frac{M}{L_{s}} V_{d s}\right. \\
& \left.-\frac{M R_{s}}{L_{s}} I_{d s}+\frac{M}{L_{s}} \omega_{s}\left(L_{s} I_{q s}+M I_{q r}\right)\right)-\dot{I}_{d r_{-} r e f} \\
\ddot{S}_{1}= & \varphi_{1}(t, x)+\gamma_{1}(t, x) V_{d r}
\end{aligned}\right.
$$


and

$$
\left\{\begin{aligned}
\dot{S}_{2}= & \frac{L_{s}}{M^{2}-L_{r} L_{s}}\left(V_{q r}+R_{r} I_{q r}+\omega_{r}\left(L_{r} I_{d r}+M I_{d s}\right)-\frac{M}{L_{s}} V_{q s}\right. \\
& \left.-\frac{M R_{s}}{L_{s}} I_{q s}-\frac{M}{L_{s}} \omega_{s}\left(L_{s} I_{d s}+M I_{d r}\right)\right)-\dot{I}_{q r_{-} r e f} \\
\ddot{S}_{2}= & \varphi_{2}(t, x)+\gamma_{2}(t, x) V_{q r}
\end{aligned}\right.
$$

Where $\varphi_{1}(t, x), \varphi_{2}(t, x), \quad \gamma_{1}(t, x)$, and $\gamma_{2}(t, x)$ are uncertain functions which satisfy

$$
\left\{\begin{array}{l}
\varphi_{1}>0,\left|\varphi_{1}\right|>\Phi_{1}, 0<\Gamma_{m 1}<\gamma_{1}<\Gamma_{M 1} \\
\varphi_{2}>0,\left|\varphi_{2}\right|>\Phi_{2}, 0<\Gamma_{m 2}<\gamma_{2}<\Gamma_{M 2}
\end{array}\right.
$$

The control algorithm proposed which is based on super twisting algorithm has been introduced by Levant [30]. The proposed high-order $\left(2^{\text {nd }}\right)$ sliding mode controller contains two parts:

$V_{d r}=u_{1}+u_{2}$

where $\left\{\begin{array}{l}\dot{u}_{1}=-\alpha_{1} \operatorname{sign}\left(S_{1}\right) \\ u_{2}=-\beta_{1}\left|S_{1}\right|^{p} \operatorname{sign}\left(S_{1}\right)\end{array}\right.$

and $V_{q r}=w_{1}+w_{2}$

where $\left\{\begin{array}{l}\dot{w}_{1}=-\alpha_{2} \operatorname{sign}\left(S_{2}\right) \\ w_{2}=-\beta_{2}\left|S_{2}\right|^{p} \operatorname{sign}\left(S_{2}\right)\end{array}\right.$

In order to ensure the convergence of the sliding manifolds to zero in finite time, the gains can be chosen as follows [29], [31].

$$
\left\{\begin{array}{l}
\alpha_{i}>\frac{\Phi_{i}}{\Gamma_{m i}} \\
\beta_{i}^{2} \geq \frac{4 \Phi_{i}}{\Gamma_{m i}^{2}} \frac{\Gamma_{M i}\left(\alpha_{i}+\Phi_{i}\right)}{\Gamma_{m i}\left(\alpha_{i}-\Phi_{i}\right)} ; i=1,2 \\
0<\rho \leq 0.5
\end{array}\right.
$$

The above proposed high-order sliding mode control strategy for a DFIG-based MCT is illustrated by Fig. 6 .

\section{VALIDATION RESULTS}

\section{A. Validation Data and Parameters}

In this work, the Raz de Sein site was chosen above several others listed in the European Commission report EUR16683 [32] due to the presence of high speed current coupled with appropriate depths suitable for marine turbine. Moreover, the marine current speed distribution for most of the time is greater than the minimum, estimated to be $1 \mathrm{~m} / \mathrm{sec}$, required for economic deployment of marine turbine [4].

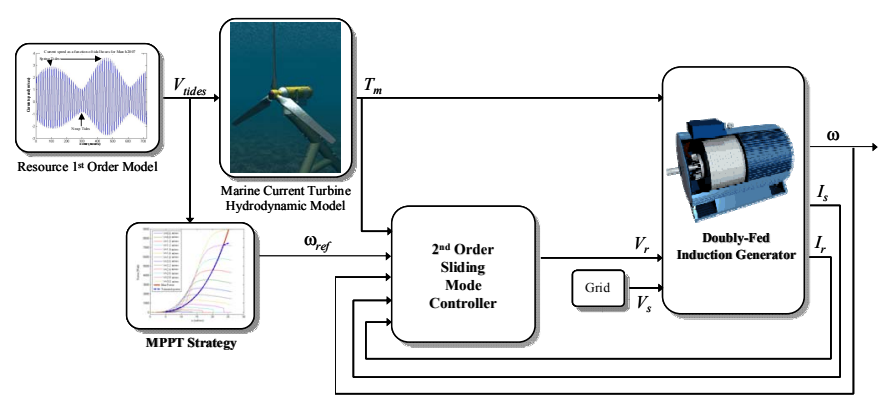

Fig. 6. The proposed control scheme.

The turbine rotor model was validated through the comparison of the simulation model with experimental data from the available literature [33-34] (Fig. 7). The adopted marine current turbine is of $1.44 \mathrm{~m}$ diameter and $7.5-\mathrm{kW}$.

In this context, the obtained power coefficient $C_{p}$ and the extractable power curves are shown by Fig. 8 .

The 7.5-kW DFIG parameters are given in the appendix.

\section{B. Validation Results for a Filtered Resource}

For speed references given by Fig. 9 (MPPT) and a filtered resource (Fig. 10), the DFIG-based MCT control performances are shown in Figs. 11, 12 and 13 respectively illustrating the rotor speed tracking performance, the reactive, and the generated active power.

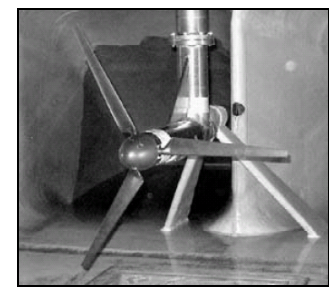

Fig. 7. The tested marine turbine [33-34]

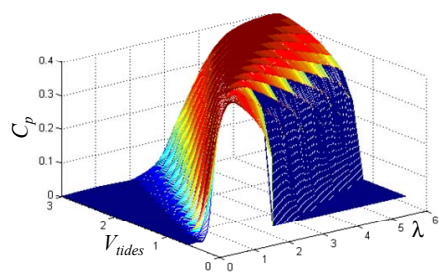

(a) $C_{p}\left(\lambda, V_{\text {tides }}\right)$ curves.

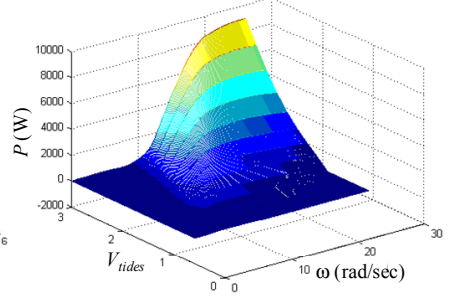

(b) The extractable power $P\left(\omega, V_{\text {tides }}\right)$. Fig. 8.

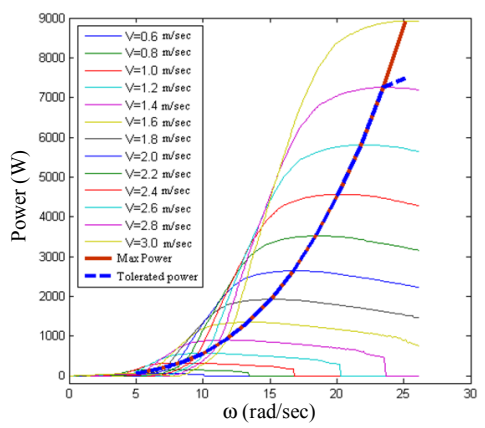

Fig. 9. Power curves for different tidal current speed. 


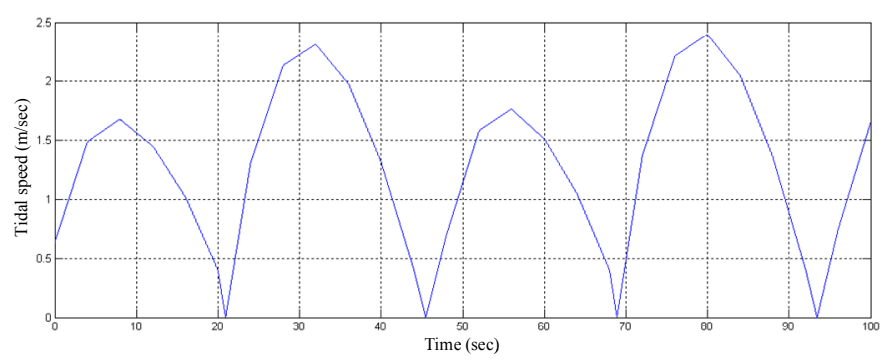

Fig. 10. Filtered resource speed.

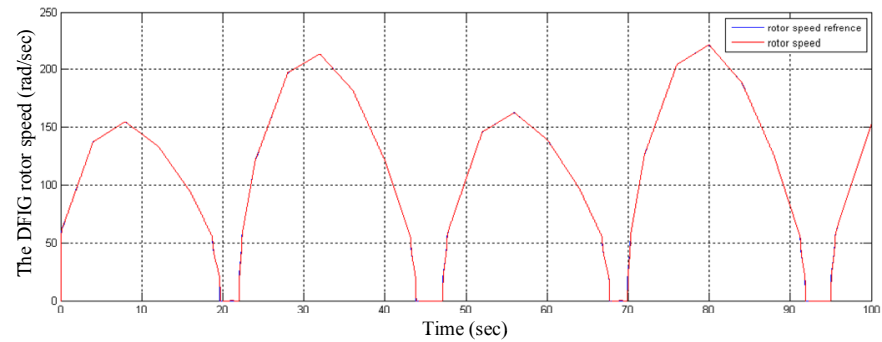

Fig.11. The DFIG rotor speed and its reference.

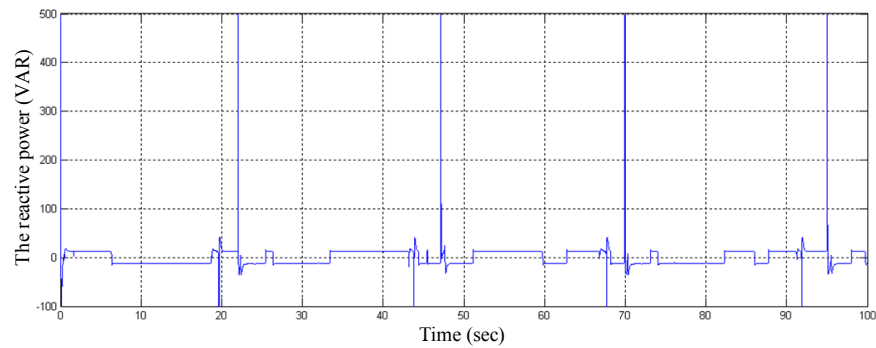

Fig.12. The DFIG reactive power.

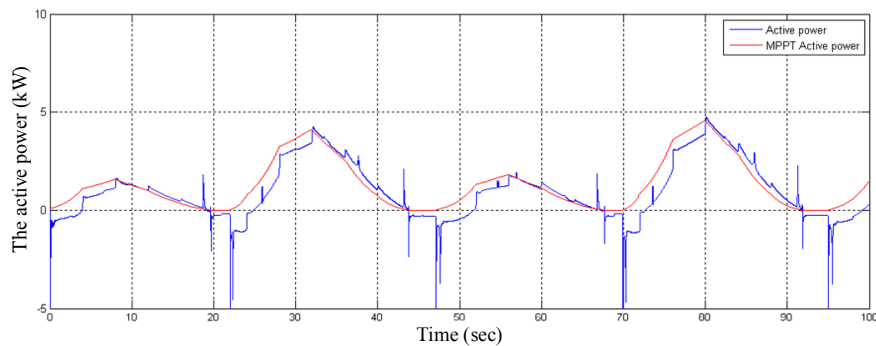

Fig. 13. The DFIG active power.

The obtained results show good tracking performances of the DFIG rotor speed, the reactive and the generated active power. Regarding [27] and as expected, the generated active power tracking is greatly improved.

\section{Validation Results for a Turbulent Resource}

Since the swell effect is considered as the most disturbing one for our resource model, a swell Stoke model is added. In this case, the speed potential is given by (Fig. 14)

$$
\left\{\begin{array}{l}
V_{\text {tides }}=\operatorname{grad} \phi \\
\phi=-\frac{H L}{2 T} \frac{\operatorname{ch} 2 \Pi\left(\frac{z+d}{L}\right)}{\operatorname{sh} 2 \Pi\left(\frac{d}{L}\right)} \sin 2 \Pi\left(\frac{t}{T}-\frac{x}{L}\right)
\end{array}\right.
$$

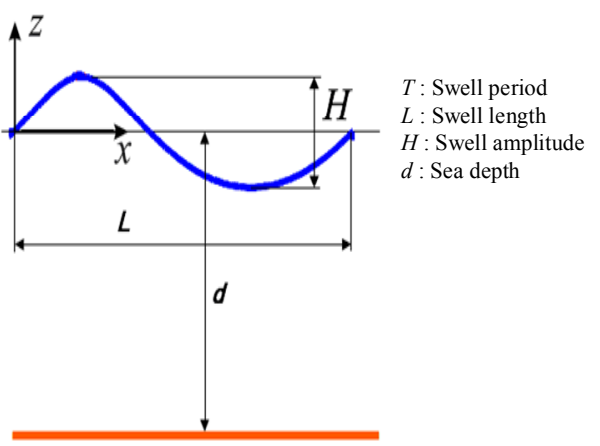

Fig. 14. Swell characteristics.

The turbulent resource characteristics are then given by Fig. 15. In this case, the DFIG-based MCT control performances are shown by Figs. 16, 17 and 18 respectively illustrating the rotor speed tracking performance, the reactive, and the generated active power. In spite of the good tracking accuracy of the high-order sliding mode control, the generated power exhibits fluctuations. In fact, these fluctuations are mainly due to accelerations and decelerations imposed to the marine current turbine by the MPPT strategy for a turbulent resource. This problem could be simply solved by filtering the resource at a certain level to avoid loosing useful powers.

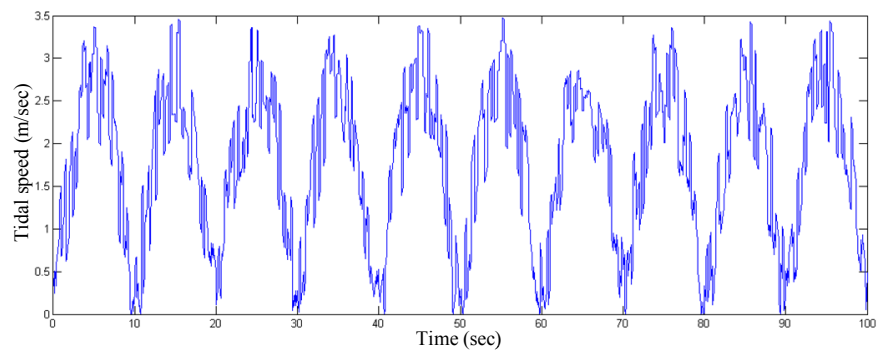

Fig.15. Turbulent resource speed.

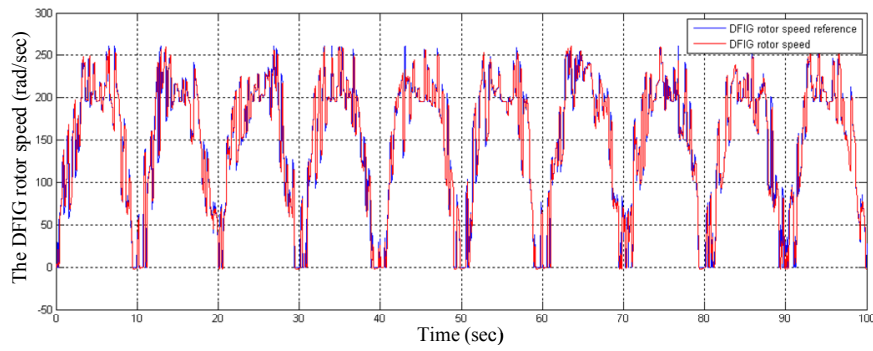

Fig.16. The DFIG rotor speed and its reference.

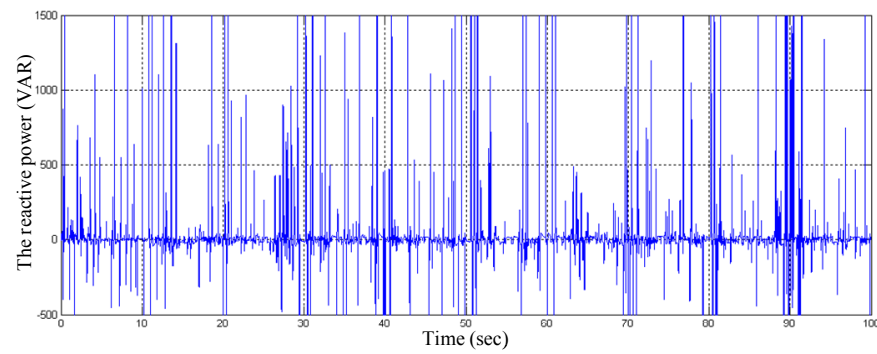

Fig.17: The DFIG reactive power. 


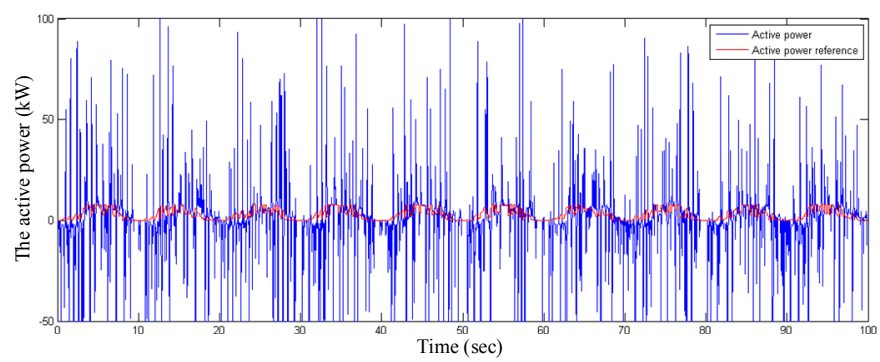

Fig. 18. The DFIG active power.

\section{CONCLUSIONS}

This paper dealt with a high-order sliding mode control of DFIG-based marine current turbine. The variable speed control strategy relies on the resource and the marine turbine models that were validated by experimental data. Tidal current data from the Raz de Sein (Brittany, France) have been used to run simulations of a $7.5-\mathrm{kW}$ prototype over various flow regimes. Simulation results have shown that the proposed control strategy is effective in terms of speed tracking and power regulation. Moreover, the sensitivity of the proposed control strategy has been analyzed regarding the swell effect. The obtained results are very encouraging even if a fluctuation effect is observed. A solution could be an efficient resource filtering.

\section{APPENDIX}

PARAMETERS OF THE USED DFIG

$R_{s}=0.455 \Omega, L_{s}=0.084 \mathrm{H}, R_{r}=0.62 \Omega, L_{r}=0.081 \mathrm{H}, M=0.078 \mathrm{H}$ $J=0.3125 \mathrm{~kg} \cdot \mathrm{m}^{2}, f=6.7310^{-3} \mathrm{Nms}^{-1}$

\section{REFERENCES}

[1] C.M. Johnstone et al., "EC FPVI co-ordinated action on ocean energy: A European platform ford sharing technical information and research outcomes in wave and tidal energy systems," Renewable Energy, vol. 31, pp. 191-196, 2006.

[2] S.E. Ben Elghali et al., "Marine tidal current electric power generation technology: State of the art and current status," in Proceedings of IEEE IEMDC'07, Antalya (Turkey), vol. 2, pp. 1407-1412, May 2007.

[3] 2005 IEEE Power Engineering Society General Meeting Panel Session, "Harnessing the untapped energy potential of the oceans: Tidal, wave, currents and OTEC," San Francisco (USA), June 2005.

[4] L. Myers et al., "Simulated electrical power potential harnessed by marine current turbine arrays in the Alderney Race," Renewable Energy, vol. 30, p. 1713-1731, 2005.

[5] J.W. Park et al., "Wide speed operation of a doubly-fed induction generator for tidal current energy," in Proceedings of the IEEE IECON'04, Busan (South Korea), vol. 2, pp. 1333-1338, 2004.

[6] J.S. Couch et al., "Tidal current energy extraction: Hydrodynamic resource characteristics," Proc. IMechE, Part M: Journal of Engineering for the Maritime, vol. 220, n4, pp. 185-194, 2006.

[7] A.S. Bahaj et al., "Fundamentals applicable to the utilisation of marine current turbines for energy production," Renewable Energy, vol. 28, pp. 2205-2211, 2003.

[8] L. Myers et al., "Power output performance characteristics of a horizontal axis marine current turbine," Renewable Energy, vol. 31, pp. 197-208, 2006

[9] E. Bossanyi, Wind Energy Handbook. New York: Wiley, 2000.
[10] W.M.J. Batten et al., "Experimentally validated numerical method for the hydrodynamic design of horizontal axis tidal turbines," Ocean Engineering, (2006), doi:10.1016/j.oceaneng.2006.04.008.

[11] W.M.J. Batten et al., "Hydrodynamics of marine current turbines," Renewable Energy, vol. 31, pp. 249-256, 2006.

[12] H. Glauert, The Elements of Airfoil and Airscrew Theory. Cambridge University Press $\left(2^{\text {nd }} E d.\right): 1959$.

[13] S. Müller et al., "Doubly fed induction generator systems," IEEE Industry Applications Magazine, vol. 8, n³, pp. 26-33, May-June 2002.

[14] J.M. Carrasco et al., "Power-electronic systems for the grid integration of renewable energy sources: A survey," IEEE Trans. Industrial Electronics, vol. 53, n4, pp. 1002-1016, June 2006.

[15] R. Pena et al., "Sensorless control of doubly-fed induction generators using a rotor-current-based MRAS observer," IEEE Trans. Industrial Electronics, vol. $55, \mathrm{n}^{\circ} 1$, pp. 330-339, January 2008.

[16] F. Bonnet et al., "Dual direct torque control of doubly fed induction machine," IEEE Trans. Industrial Electronics, vol. 54, n5, pp. 24822490, October 2007.

[17] G. Iwanski et al., "Sensorless direct voltage control of the stand-alone slip-ring induction generator," IEEE Trans. Industrial Electronics, vol. 54, n², pp. 1237-1239, April 2007

[18] G. Tapia et al., "Proportional-integral regulator-based approach to wind farm reactive power management for secondary voltage control," IEEE Trans. Energy Conversion, vol. 22, n², pp. 488-498, June 2007.

[19] L. Xu et al., "Direct active and reactive power control of DFIG for wind energy generation," IEEE Trans. Energy Conversion, vol. 21, n³, pp. 750-758, September 2006

[20] R. Cardenas et al., "MRAS observer for sensorless control of standalone doubly fed induction generators," IEEE Trans. Energy Conversion, vol. 20, n4, pp. 710-718, December 2005.

[21] A. Mirecki et al., "Architecture complexity and energy efficiency of small wind turbines," IEEE Trans. Industrial Electronics, vol. 54, $\mathrm{n}^{\circ} 1$, pp. 660-670, February 2007.

[22] M.M. Hand et al., "Advanced control design and field testing for wind turbines at the National Renewable Energy Laboratory," NREL/CP-50036118, May 2004

[23] Y.D. Song et al., "Variable speed control of wind turbines using nonlinear and adaptive algorithms," Journal of Wind Engineering and Industrial Aerodynamics, vol. 85, pp. 293-308, 2000.

[24] K.D. Young et al., "A control engineer's guide to sliding mode control," IEEE Trans. Control Systems Technology, vol. 7, n³, pp. 328-342, May 1999.

[25] B. Beltran et al., "Sliding mode power control of variable-speed wind energy conversion systems," IEEE Trans. Energy Conversion, vol. 23, n॰2, pp. 551-558, June 2008.

[26] D. Xiang et al., Control of a doubly fed induction generator in a wind turbine during grid fault ride-through," IEEE Trans. Energy Conversion, vol. 21, n³, pp. 652-662, September 2006.

[27] S.E. Ben Elghali et al., "Modeling and MPPT sensorless control of a DFIG-based marine current turbine," in Proceedings of the ICEM'08, Vilamoura (Portugal), September 2008.

[28] E. Koutroulis et al., "Design of a maximum power tracking system for wind-energy-conversion applications," IEEE Trans. Industrial Electronics, vol. 53, n², pp. 486-494, April 2006.

[29] A. Levant et al., "Integral high-order sliding modes," IEEE Trans. Automatic Control, vol. 52, n7, pp. 1278-1282, July 2007.

[30] L. Fridman and A. Levant, Sliding Mode Control in Engineering, Marcel Dekker, Inc., 2002, Chap. 3 Higher Order Sliding Modes, pp. 53-101.

[31] H.K. Khalil, Nonlinear Systems. Mc Millan Publishing: New York, 1992.

[32] EU Commission, "The exploitation of tidal marine currents," Report EUR16683EN, 1996.

[33] S.E. Ben Elghali et al., "A simulation model for the evaluation of the electrical power potential harnessed by a marine current turbine," IEEE Journal on Oceanic Engineering, vol. 32, n4, pp. 786-797, October 2007.

[34] A.S. Bahaj et al., "Power and thrust measurements of marine current turbines under various hydrodynamic flow conditions in a cavitation tunnel and a towing tank," Renewable Energy, vol. 32, pp. 407-426, 2007. 